\title{
Changes in the demand and supply for milk and dairy products
}

\section{By D. J. RoBerTs, Milk Marketing Board, Thames Ditton, Surrey KT7 OEL}

Milk production is one of the most important enterprizes in UK agriculture and milk and dairy products are an essential staple food for the majority of the population, making a significant contribution to dietary intake and accounting for $15.7 \%$ of household expenditure on food. But the relation between the amount of milk produced in the UK and consumer demand has not been that close in the past, as other factors have had a far greater influence.

The UK market for dairy products has traditionally been unique amongst large countries in that it has depended to varying degrees on imports to satisfy consumer demand. Because of this important factor the supply of milk products in the UK has not been related to consumer demand, but has been more particularly influenced by government policies and the influence of these policies on producers' economic circumstances.

In the earlier part of this century, UK governments concentrated mainly on a cheap food policy which encouraged imports and did not provide the best economic environment to encourage increased milk production. Even in the post-war period, when there was a recognition of the need to maintain a viable agricultural industry in the UK, the policy still largely looked to milk supplies to meet the liquid market requirements, with a buffer to cover seasonal fluctuation in supply. This did not stop milk production from gradually increasing, as farmers improved technical efficiency on their farms and the genetic potential of the national dairy herd increased through the use of artificial insemination. Milk producers also responded to adverse economic situations by increasing production as a means of meeting their ever-growing basic costs. As a result, from 1956 to 1966 , production increased by $21 \%$ and in the next 10 years by a further $25 \%$.

This process accelerated following the accession of the UK into the European Economic Community (EEC) in 1973 and UK production reached a peak in 1982-83 (Table 1). There was government encouragement to expand production, with the objective of making the UK more self-sufficient, and import saving was seen as a desirable objective. At the same time the EEC Commission was providing grants for the improvement of farm structure, which inevitably resulted in increased production.

However, the same thing was happening in all other EEC countries, with the rise in production being even more rapid in some countries than others. But consumer demand did not increase at the same rate and despite ever-increasing exports of dairy products outside the EEC, stocks of butter and skim-milk powder built up to unacceptable levels. The cost to the EEC budget of dealing with these surpluses escalated and after endless talking and threats, a sudden decision was made in 1984 to impose a quota system to control total EEC output.

Inevitably this had a dramatic effect on milk producers throughout the EEC. Milk production declined immediately in the UK by $7.3 \%$ to below the allocated quota and had only slightly recovered by 1986-87. A further reduction in quota was imposed for $1987-8$, with more severe penalties for over-production, so that production is expected to be down to the level that it was 10 years previously.

It is interesting to note that the size of the national dairy herd has remained relatively stable throughout this period, despite a $40 \%$ rise in output over the last 30 years. This has come from a significant increase in yield per cow and in addition the compositional 
Table 1. UK milk supplies between 1976 and 1987

$\begin{array}{lccc}\text { Milk output } & \text { Average yield } \\ \left(\times 10^{6} 1\right) & \begin{array}{c}\text { Dairy cows } \\ \left(\times 10^{3}\right)\end{array} & \begin{array}{c}\text { per cow } \\ (1)\end{array} \\ 1976-77 & 13647 & 3228 & 4275 \\ 1982-83 & 16373 & 3246 & 5055 \\ 1986-87 & 15364 & 3135 & 5015 \\ \text { UK quota } & & & \\ 1987-88 & 14509 & & \end{array}$

quality of milk has also improved, with average butterfat levels increasing over the period from 3.81 to $3.95 \%$. It is only since the imposition of quotas that we have begun to see a slight decline in the size of the national herd.

Individual milk producers have had to react to the economic pressures imposed on them, most of which have had a strong political influence. Some have responded by adopting more modern techniques and improving technical efficiency, but many others have given up milk production and left the industry. Producer numbers reduced by almost 40\% between 1966 and 1976 (71 197 in March 1976) and the decline has continued ever since, with a 34\% drop over the next 10 years (52221 in March 1982, 46740 in March 1987). This has resulted in the average herd size increasing over this 20 -year period from twenty-five cows to sixty-seven.

The increase in UK milk production has led to the government objective of greater self-sufficiency being achieved, albeit assisted by a decline in consumer demand (Table 2 ). The increase in milk supplies primarily resulted in increased production of cheese and butter, but this had to compete with imported products that already had an established place in our market, much of it sold at relatively low prices. Therefore, in order to show an economic return, UK manufacturers have had to look to increase exports of dairy products and make use of EEC intervention schemes.

Far more attention has been paid by the dairy industry in recent years to new product development, in order to maximize returns and to meet the rapid change in consumer demand. The liquid milk market still remains the most important, but this has also seen a lot of change.

Liquid milk consumption in the $\mathrm{UK}$ is high compared with many other countries and it has always accounted for the utilization of a high proportion of UK output. This was as high as $70 \%$ in the mid $1960 \mathrm{~s}$, but has declined as milk supplies have increased (Table 3 ). Total consumption has also been gradually declining for the last 10 years and many factors have contributed to this decline. Even here, government policies have had a part to play. A substantial consumer subsidy on the retail price of milk in 1974-75 pushed liquid sales to a peak in 1976-77, but its inevitable removal resulted in a rapid rise in the retail price, which had an adverse effect on sales.

Table 2. UK self-sufficiency ratio (\%)

$\begin{array}{ccccc}\text { Year } & \text { Butterfat } & \text { SNF } & \text { Butter } & \text { Cheese } \\ 1976 & 63 & 107 & 20 \cdot 1 & 59 \cdot 8 \\ 1982 & 83 & 120 & 72 \cdot 1 & 64 \cdot 9 \\ 1986 & 93 & 110 & 89 \cdot 0 & 61 \cdot 6\end{array}$

SNF, solids-not-fat. 
Table 3. UK liquid milk market

$\begin{array}{lccc}\text { Year } & \begin{array}{c}\text { Total sales } \\ \left(\times 10^{6} l\right)\end{array} & \begin{array}{c}\text { Percentage of } \\ \text { supplies }\end{array} & \begin{array}{c}\text { Consumption per capita } \\ (\text { /year })\end{array} \\ 1976-77 & 7689 & 56 \cdot 3 & 138 \cdot 3 \\ 1982-83 & 6954 & 42 \cdot 5 & 125 \cdot 3 \\ 1986-87 & 6834 & 44 \cdot 5 & 122 \cdot 7\end{array}$

Similarly, the national provision of free milk for school children was withdrawn in the early 1970 s and the provision of welfare milk drastically reduced. Together they accounted for $16 \%$ of sales in 1970 , compared with only $4 \%$ today.

Children are responsible for a large proportion of the milk drunk 'neat' at home, so the number of children in the population at any one time can have a significant effect on consumption. Since the mid-1970s there has been a gradual decline in the child population of the UK, which has had its effect on milk consumption.

There have also been major changes in the nation's eating and drinking habits. The traditional family three-course meal has been declining in popularity for many years, with more interest in labour-saving dishes and 'snacking'. This has resulted in less milk being used in cooking, as housewives rely more on ready-prepared meals and in particular a decline in home-made puddings. But on the benefit side, breakfast cereal consumption has grown. They are now eaten at all times of the day and this market now accounts for $17 \%$ of milk usage in the home.

The amount of milk added to other drinks in the UK has always been very high and currently accounts for $42 \%$ of household consumption. This compares with a far higher amount of milk drunk on its own in other countries. More milk is used in tea than in coffee, so as the consumption of coffee has been increasing, this has been to the disadvantage of milk consumption. There has also been a decline in the popularity of hot-milk drinks at bedtime and water-based substitutes are now becoming increasingly available.

Milk as a drink, both in and out of the home, has suffered relentless competition from soft drinks. Their range of product, packaging and availability has increased and the low raw material costs enable them to be extensively promoted. The consumption of soft drinks by children in particular has significantly increased and efforts have been made to modernize the image of milk in order to compete in this sector.

Milk has traditionally had a good image with most consumers, especially housewives, but in recent years it has seen a decline. Milk is not now seen to be as essential a part of the diet as it used to be and there is concern and misunderstanding about its fat content. This has been partly due to increasing consumer interest in the link between diet and health and has resulted in more consumer demand for a wider choice of milks.

Skimmed milk has been available for many years, particularly in shops, but the demand was small and associated with slimming diets. The growing consumer interest in low-fat products has led to the increasing availability of both skimmed and semi-skimmed milks, first in shops and then on the doorstep. Their growth in market share has been rapid and the retail value of this market is now over $£ 400$ million (Table 4). However, it is not easy to say what effect this growth has had on total milk consumption, as so many other factors are influencing the market at the same time. Their availability may have allayed the fears of some people concerned about fat intake, but on the other hand skimmed milk, which represents $11 \%$ of the household market, has a low taste rating and cannot encourage consumption. 
Table 4. Household consumption of low-fat milks in England and Wales

$\begin{array}{lcc}\text { Year } & \begin{array}{c}\text { Volume } \\ \left(\times 10^{6} 1\right)\end{array} & \begin{array}{c}\text { Percentage of } \\ \text { total houschold } \\ \text { consumption }\end{array} \\ 1982 & 192 & 2 \cdot 3 \\ 1984 & 494 & 9 \cdot 2 \\ 1986 & 1025 & 19 \cdot 7\end{array}$

Table 5. Estimated structure of the liquid-milk market in England and Wales (\%)

$\begin{array}{lr}\text { Household purchases } & \mathbf{8 8 . 7} \\ \text { Catering market (including schools) } & 8 \cdot 3 \\ \text { Other uses } & 3 \cdot 0\end{array}$

Another response to consumer demand has been the increasing availability of milk in shops, now accounting for $20 \%$ of household milk purchases. Changing household and shopping patterns have encouraged this trend and it has provided a stimulus to increase consumer choice. Flavoured milk and high-fat breakfast milk have found a market share, together with specialist products such as lactose-reduced and calcium-enriched milks. Larger containers are now available and in some supermarket groups 4-pint containers are extremely popular.

Again, it is difficult to say what effect this has had on overall consumption. It appears that households purchasing milk both on the doorstep and from shops have a higher level of milk consumption than average, but those that purchase only from shops are significantly lower. It is still believed that doorstep delivery is an important factor in the high level of milk consumption in the UK and every effort is being made to preserve its availability and its share of the total market.

The catering market (including schools) accounts for over $8 \%$ of liquid milk sales and with the increasing trend to more eating out of home, this sector is becoming more important (Table 5). The development of refrigerated milk dispensers, with milk provided in a 'box', proved most acceptable to caterers and they are now in general use. In order to counter the challenge from soft drinks, flavoured milks and milk shakes are becoming increasingly available and growing in popularity. The challenge to the industry is to make milk, both plain and flavoured, as widely available as soft drinks, particularly in the rapidly-growing vending market.

Although there can be a degree of optimism about future levels of liquid sales, this is not the case with butter. This market has seen a steady loss of sales to margarine for many years and at present the decline is accelerating (Table 6). The majority of consumers continue to agree that they prefer the taste of butter to other spreads but other factors seem to have a much greater influence on what is purchased. The availability of a cheap alternative in margarine, often as low as one-third of the price of

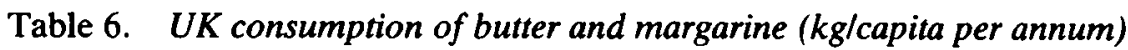

$\begin{array}{ccc}\text { Year } & \text { Butter } & \text { Margarine } \\ 1976 & 8 \cdot 3 & 5 \cdot 8 \\ 1982 & 5 \cdot 6 & 7 \cdot 4 \\ 1985 & 5 \cdot 0 & 7 \cdot 3\end{array}$


Table 7. Market share in the UK yellow-fats market (\%)

$\begin{array}{cccc}\text { Year } & \text { Butter } & \text { Margarine } & \text { Spreads } \\ 1982 & 37 & 60 & 3 \\ 1986 & 29 & 56 & 15\end{array}$

butter, is the major factor but a choice on price may often be justified by the customer on the grounds of convenience, lower energy or, in particular, health. Effective public relations campaigns by margarine manufacturers over many years, based on the claimed benefits of high-polyunsaturated-fat margarine, have created a beneficial image for all margarines, even for those as highly saturated as butter, and current concern about fat intake has benefited the sale of low-fat spreads.

The general availability of refrigerators and the growing importance to the consumer of convenience foods has made spreadability an important factor which butter at present cannot counter. The greater profit potential from margarine has also resulted in its receiving far greater advertising support than butter.

A wide choice of different brands of margarine has been available for many years, but the recent expansion of 'other spreads' in the yellow-fats market has expanded consumer choice even further, to the point where there is obvious confusion. These consist of low-fat spreads, with a $\mathbf{4 0 \%}$ fat content of mainly vegetable fat, and dairy-based spreads which contain a mixture of butterfat and vegetable fat. Many of the dairy-based spreads are produced by dairy companies and are seen to be the only way for them to remain competitive in a continually declining market. They have proved popular with consumers and their share of the market continues to expand, but they have been taking sales away from butter as well as from margarine (Table 7).

Work is being done to investigate the technical and economic possibility of producing a more spreadable butter and, in the longer term, to reduce the proportion of saturated fat in butter. But all indications are that butter sales will continue to decline and, despite the growth of dairy-based spreads, butterfat consumption in this sector will go down.

The cheese market, however, has been more buoyant and shows gradual growth ( $\mathrm{kg} /$ capita per annum: $1976,6 \cdot 1 ; 1982,6 \cdot 7 ; 1985,7 \cdot 2)$ although the level of consumption in this country is still far below that of most other European countries. The UK market is still dominated by Cheddar cheese, which accounts for $60 \%$ of household consumption with traditional territorial cheeses making up another $16 \%$.

The growth in the market in recent years has been mainly in soft cheeses and imports of continental varieties have increased. But British manufacturers have responded to the growth in this sector and a far wider range of English-made cheeses is now available.

Although this wide choice in cheese has undoubtedly stimulated demand, the majority of consumers still only purchase one variety of cheese. We do not have the continental tradition of eating cheese for breakfast or regarding it as an essential part of a meal, yet consumers have very positive attitudes to cheese both with regard to its versatility and its nutritional value. Cheese has the big advantage of convenience of use and it is expected that this market will continue to grow.

Consumers still regard cream as a form of indulgence that is relatively expensive, yet consumption continues to rise (kg/capita per annum: 1976, 0.67; 1982, 0.72; 1985, 0.76). Cream has a very high quality image, and with increasing consumer affluence and more competitive pricing it is becoming affordable more often to more people. It may not have a good health image, but as it is seen as only an occasional item in the overall diet it is largely regarded as acceptable, even by those consumers who would normally select low-fat products. 
The market is diverse but is showing growth in all sectors. Household purchases of fresh cream continue to expand ( $36 \%$ of the market) and UHT creams have helped to extend availability in the home. But competition is increasing from cream substitutes which have improved in quality, position themselves as healthier products and offer a price advantage to the consumer. However, with the gradual widening of the use of cream to savoury cooking, the total market is expected to continue to grow.

Cream cakes, fresh and frozen, are an important outlet for cream and are a buoyant market (33\% of the market). Again, despite adverse health imagery, they are perceived by an increasing number of consumers as a permissible, affordable treat. The market was once predominantly based on fresh-cream cakes from small bakers, but the development of superstores with in-store bakeries has increased availability and the extended ownership of freezers has widened the market potential for frozen cakes.

With more people eating out of home and expecting better quality food, cream in catering ( $22 \%$ of the market) is benefiting from the quality image it can convey, as well as the contribution it can make to taste.

A rapidly expanding market which has capitalized on a very positive health image is that of yoghurt. Although overall consumption is not high compared with that in some other countries, it has almost doubled in the UK in the last 10 years $(\mathrm{kg} /$ capita per annum: $1976,1 \cdot 7 ; 1982,2 \cdot 3 ; 1985,3 \cdot 0$ ). One factor that has encouraged growth has been the increasing diversity of consumer choice. In contrast to the continent where the major market is for plain yoghurt, flavoured yoghurts of all types predominate in the UK. Low-fat varieties have the major market share, but recent developments have come from the richer, higher-fat yoghurts.

Other dairy-based products are following in this field of convenience desserts, offering the consumer a wide choice. Price does not seem to be the main criterion, the emphasis being on taste and quality.

In many countries ice cream is required to be made with butterfat and this forms an important market for the dairy industry. In the UK, however, vegetable fats have traditionally been used and it has been suggested that this may be one of the reasons why the level of consumption is so much lower than in other countries. But the growing consumer interest in better-quality products is also being seen in this market and whilst overall ice cream consumption is static, increasing quantities of dairy ice cream, much of it using fresh cream, are being sold (Table 8). But the retail price premium for dairy ice cream is severe, and despite growing consumer demand there will be a limit to the potential growth of this market.

I have now looked at all the major markets for milk and dairy products, some growing and some declining. But it is difficult from this type of survey to get an overall picture of what this means in terms of total market requirement for milk.

In the case of most dairy products and increasingly for the liquid market, milk is a source of raw materials that can be used to produce a range of products as required. So we must look at the demand for component parts of milk and this can best be seen by

Table 8. UK ice cream market $\left(£ \times 10^{6}\right)^{*}$

$\begin{array}{ccc}\text { Year } & \text { Standard ice cream } & \text { Premium ice cream } \\ 1984 & 162 & 12 \\ 1985 & 147 & 14 \\ 1986 & 148 & 19 \\ & & \\ & \text { *Source: Walls. }\end{array}$


Table 9. Consumption of butterfat in different countries ( $\mathrm{kg} / \mathrm{capita}$ per annum)

$\begin{array}{cccccc}\text { Year } & \text { UK } & \text { Ireland } & \text { France } & \text { Germany } & \text { USA } \\ 1980 & 13.5 & 18.7 & 15.0 & 11.8 & 8.9 \\ 1982 & 12.8 & 20.1 & 14.8 & 11.9 & 8.8 \\ 1985 & 12.0 & 15.5 & 15.3 & 12.5 & 9.2\end{array}$

looking at the level of butterfat consumption in the UK (Table 9). Despite increased usage in some sectors, the decline in the butter market and the swing to low-fat milks has resulted in an $11 \%$ reduction over a 5-year period, and all the indications are that this decline will continue. A similar situation exists in the Republic of Ireland, but in other countries the situation is more stable. Although consumption is higher in some countries than in the UK, in others such as the USA, Australia and Canada it is much lower.

Skim-milk powder supplies are already far in excess of the requirement for human consumption in the EEC and large quantities are currently being used for animal feed, heavily subsidized to make the product competitive with vegetable proteins. With a declared objective to bring supply and demand into balance, it would appear that any further declines in consumer demand for butterfat are likely to result in further reductions in production quotas in the long term.

Much work is being done to investigate alternative economic markets for butterfat, but the price differential with vegetable fats is a major obstacle. The challenge for the future is for the industry to continue to provide consumers with a range of products and to promote them positively.

Consumers vary greatly in their requirements and a wide choice of milks and dairy products must be made available. The market for low-fat products will continue to expand and if consumers are not offered low-fat dairy products, they will certainly be offered vegetable-based alternatives. But the interest in quality and taste is also just as important, as consumers increasingly look to food for enjoyment, and this offers the opportunity of producing value-added products which can enhance producer returns.

Consumer choice does not take place in a vacuum and can be significantly influenced by advertising and promotional activity. Competitive products such as soft drinks and margarine receive heavy support, as do the increasing range of substitute products. The image of milk and dairy products has sometimes been attacked in over-simplified advice on reducing fat intake and the industry has therefore been endeavouring to communicate the positive attributes of its products and the important part which they can play in a healthy balanced diet.

The situation in the UK market is not dissimilar to that being faced in many other countries where there is also a need to balance supply with demand. Milk and dairy products do not have a guaranteed level of consumption and they must compete for their share of the consumer's purse like all other food products. But they do have great advantages in taste, quality and nutritional value, as well as the flexibility for product development, so it is up to the dairy industry to ensure that consumers are offered the products they want and that these are given sufficient advertising and promotional support. 